\title{
FORMULATION AND EVALUATION OF CONTROLLED RELEASE IBUPROFEN TABLETS
}

\author{
Eman M. Samy', Ahmed O.Abdel Zaher ${ }^{2}$ and Safaa A.Abdel Maksoud ${ }^{3}$ \\ ${ }^{1}$ Department of Industrial Pharmacy, Faculty of Pharmacy, ${ }^{2}$ Department of Pharmacology \& \\ ${ }^{3}$ Department of Histology, Faculty of Medicine, Assuit University, Egypt
}

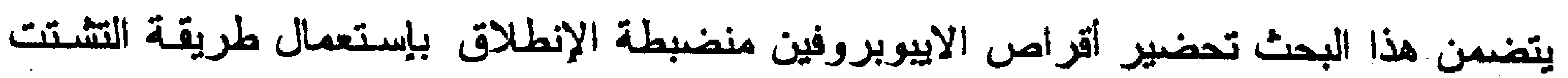

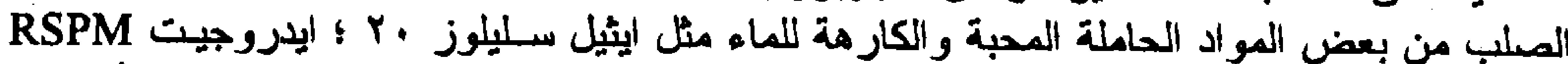

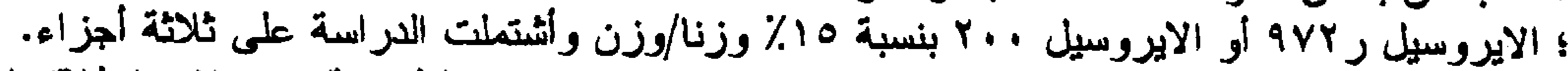

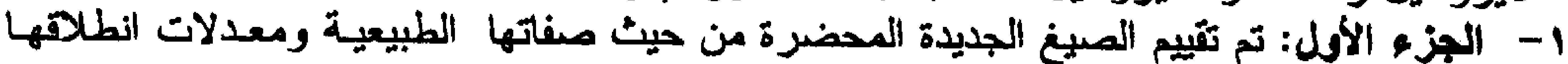

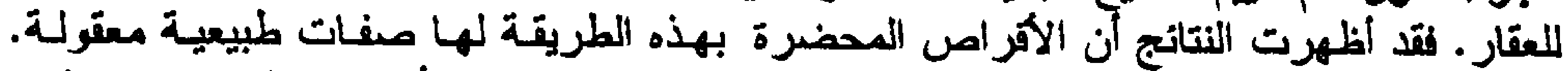

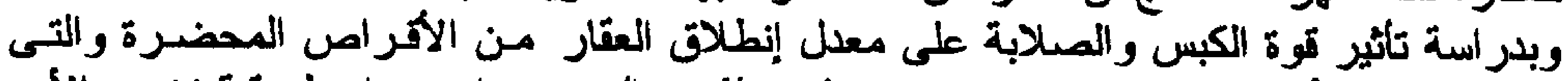

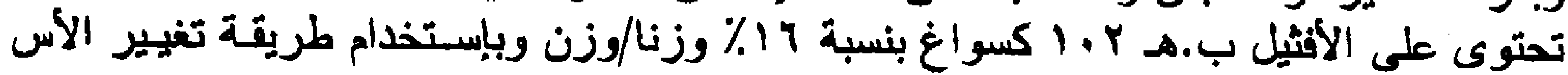

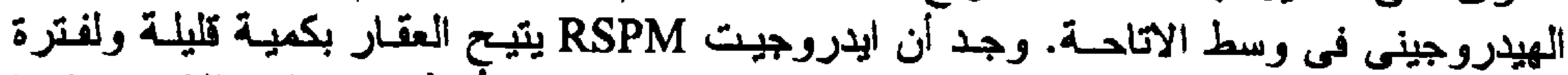

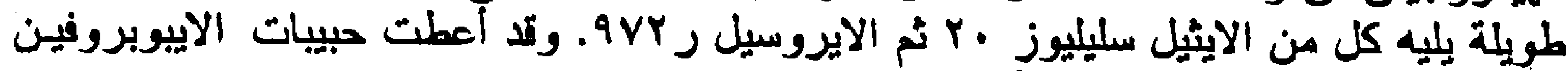

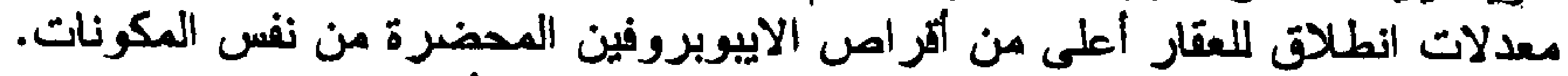

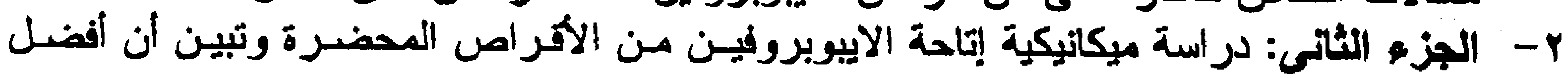

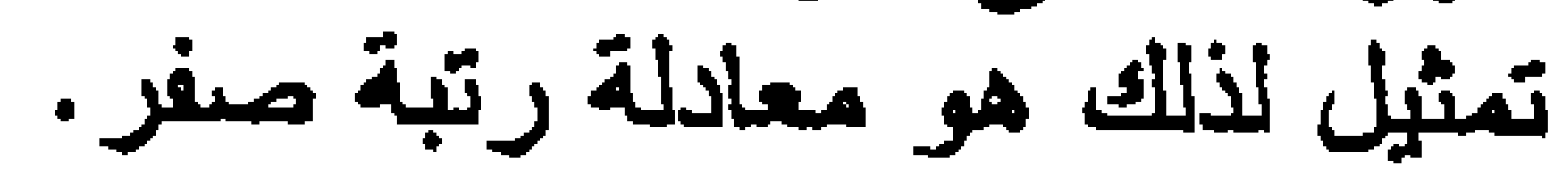

$$
\begin{aligned}
& \text { الجانبية للعقار . المثابه } \\
& \text { تأثير اتها على أنسجة المعدة. }
\end{aligned}
$$

Controlled release ibuprofen tablets were prepared by coevaporation technique using Eudragit RSPM, ethylcellulose 20, Aerosil R972 and Aerosil 200 as carriers and Avicel pH102 as filler. The effect of different compression forces on the release rate of the drug was studied. The carriers used produce retardation in the release rate of ibuprofen in the following manner: Eudragit RSPM > ethylcellulose $20>$ Aerosil $R 972>$ Aerosil 200. The dependence of release rate $(K)$ on hardness $(H)$ may be approximated by the equation, $\operatorname{Ln} K=\alpha H+\beta$. The release mechanism follows zero order kinetic.

The antiinflammatory activity of the coevaporates was studied in albino rats using trypan-blue method. The coevaporates were also tested in albino mice for their analgesic activity using hot plate and p-benzoquinone induced writhing methods. The obtained results revealed that Eudragit RSPM and Aerosil 200 were the most effective in sustaining the antiinflammatory and analgesic actions of ibuprofen, while ethylcellulose 20 was the least effective. Histological examination of rat's stomach proved the efficiency of the tested coevaporates in inhibiting the ulcerogenic effects caused by the plain drug.

Received in 19/6/1995 \& Accepted in 29/2/1996 


\section{INTRODUCTION}

Antiinflammatory drugs are often used for long course treatment in patients with chronic and disabling conditions. The gastrointestinal complaints were the most symptoms encountered with medications of these drugs ${ }^{1}$. Ibuprofen is a non-steroidal antiinflammatory agent that possesses analgesic and antipyretic activities. The drug has a relatively short half life of about 2 hours $^{2}$ and therefore an ideal condidate for formulation as a controlled release dosage form. These facts together with the problems encountered with the peptic ulceration effect of the drug predomenate our investigation to formulate ibuprofen by coevaporation with ethylcellulose 20, Eudragit RSPM, Aerosil R972 and Aerosil 200.

Kurumaddall et $a l .^{3}$, obtained sustaind release forms of ibuprofen beads using cellulose acetate phthalate and other polymers (K $100 \mathrm{M}$ Methocel and K 100 LV Methocel). Christianah and James ${ }^{4}$ prepared ibuprofen microspheres from wax using a congeable encapsulation method. The application of wet granulation technique to control the release rate of ibuprofen from Eudragit matrices was reported ${ }^{5}$.

Preparation of ibuprofen granules using different types of enteric coating agents as inert carriers by coevaporation method and the physicochemical properties have been previously reported ${ }^{6}$. The objectives of this study were (i) formulation of ibuprofen granules into tablets, (ii) evaluation of the effect of various types of carriers and variation of compression forces on the release rate of ibuprofen from tablets using a release medium of variable $\mathrm{pH}$ (iii) establishment of the release mechanism of the drug under these conditions and (iv) evaluation of the antiinflammatory, analgesic and erosive activities of ibuprofen and its coevaporates.

\section{EXPERIMENTAL}

\section{Materials}

Ibuprofen (Francis, S.P., Via Oiriggo, Italy), Eudragit RSPM (Röhm Pharma. GMBH, West Germany), Ethylcellulose 20 (Laserson and
Sabetay, Paris), Aerosil 200, Aerosil R972 (Vor Feuchtigkeit Shutzen Betriebs-Kontrolle, Germany), microcrystalline cellulose (Avicel pH 102, FMC Corporation, American Viscose, USA) and magnesium stearate (Prolabo, France) were used as supplied. Hydrochloric acid (37\%), dibasic sodium hydrogen phosphate $\left(\mathrm{Na}_{2} \mathrm{HPO}_{4}\right.$. $12 \mathrm{H}_{2} \mathrm{O}$ )(Prolabo, Paris), ethanol and acetone were of analytical grade and used as received. Histamine phosphate (Merck Sharp Co.), trypan-blue (Prolabo Co.) and p-benzoquinone (Prolabo Co.) were used.

\section{Equipment}

- Dissolution apparatus (Erweka apparatebeau, Germany).

- UV/VIS Spectrophotometer (Perkin Elmer, 550 se Spectrophotometer).

- $\quad$ Single punch tablet machine, fitted with 12 $\mathrm{mm}$ flattened punches (Korsch EK/O, Berlin, Germany).

- Primax mixer (KL-Kupper und Elektronische, D, 5357, Germany).

- Turbula mixer (Willey, A.Bachofen Machinen Febrick, Basel, Switzerland).

- Hardness tester (Erweka TBT).

- Friabilator (Erweka TAB).

\section{Methods}

\section{1- Tablets preparation}

Coevaporates of ibuprofen using $15 \% \mathrm{w} / \mathrm{w}$ carrier were prepared ${ }^{6}$. The product was thoroughly mixed with $16 \%$ w/w Avicel pH102 as filler for 10 minutes to produce a homogeneous preparation. Magnesium stearate $(1 \% \mathrm{w} / \mathrm{w})$ was added and mixed for 5 minutes. The materials were tabletted at various compression forces.

\section{2- Evaluation of Tablets}

Weights uniformity, hardness as well as friability were evaluated.

\section{3- Release studies of tablets}

A shift dissolution method as reported in the previous paper ${ }^{5}$ was employed:

$0-1$ hr. pH 1.5, 1- 2 hr. pH 2.6, 2- 3 hr. pH 6.6, 
4- 5 hr. pH 7.1,

5- 6 hr. pH 7.2.

The tablet containing $300 \mathrm{mg}$ of drug was placed in $1000 \mathrm{ml}$ of the release medium at 37 $\pm 0.5^{\circ} \mathrm{C}$. The stirring rate was $50 \mathrm{rpm}$. Filtered samples were withdrawn manually at predetermined time intervals and assayed spectrophotometerically at $222 \mathrm{~nm}^{5}$. All release experiments were carried out in duplicate and the mean values are reported. The used carriers and filler were tested for interference with the assay procedure, and no interference was detected.

\section{4- Storage conditions}

In order to study the physical stability of ibuprofen tablets, the samples were kept in a desiccator maintained at $45^{\circ} \mathrm{C} / 40 \%$ relative humidity (R.H.) for 6 months.

\section{5- Evaluation of the antiinflammatory activity}

The antiinflammatory activity of the drug or its coevaporate granules under investigation was studied in rats using the trypan-blue method described by Golikov ${ }^{7}$. This method depends on the quantitative determination of the effect of ibuprofen or its coevaporates on the rate of capillary permeability disturbance induced by intradermal injection of a phlogogenic substance such as histamine. The rate of capillary permeability was calculated as the time taken for the appeawnce of a blue colour around the site of the intradermal injection of histamine phosphate $(0.02 \mathrm{ml}$ of $0.1 \%$ solution) following an intravenous injection of $2 \mathrm{mg} / \mathrm{kg}$ of a solution of the trypan-blue dye. Suspensions of each tested coevaporates or plain ibuprofen in 5\% gum acacia were orally administered to different groups of adult albino rats $(200-260 \mathrm{~g})$ in a dose equal to $50 \mathrm{mg} / \mathrm{kg}$ of the active ingredient. The antiinflammatory activity was estimated after oral administration at 2, 4, 6 and 8 hours. One group of rats was used for each time interval. Control animals were treated similarly after oral administration of a $5 \%$ suspension of gum acacia.

\section{6- Evaluation of the analgesic activity}

The analgesic activity of ibuprofen and each of its coevaporate granules under investigation was studied in mice using two different methods:

\section{A- Hot plate method}

In this method, the time taken by the mouse to lick its feet or to jump within a plexiglass cylinder placed on a hot plate surface $\left(55^{\circ} \mathrm{C}\right)$ was determined. This reaction time was taken as the end point ${ }^{8}$ and the increase in hot plate latency was taken as a measure of the analgesic activity of the tested coevaporates. Suspensions of the tested coevaporates and plain ibuprofen in $5 \%$ gum acacia were orally admininstered to different groups of adult albino mice (20-28 $\mathrm{g}$ ) in a dose equal to $50 \mathrm{mg} / \mathrm{kg}$ of the drug. The analgesic activity was evaluated at 2, 4, 6 and 8 hours after administration. Control animals were treated with $5 \%$ suspension of gum acacia.

\section{B- Writhing method}

The analgesic activity of the investigated coevaporates was also studied using p-benzoquinone writhing method in mice ${ }^{9}$. Before carrying out the experiments, a sensitivity test was done to determine the sensitivity of mice to p-benzoquinone. In this test, animals were given an intraperitoneal injection of $0.25 \mathrm{ml}$ of $0.02 \%$ solution of p-benzoquinone in water. The animals were observed for writhing during a period of one hour. Only animals which responded to p-benzoquinone by writhing were used in the main experiment, not less than 48 hours later.

Suspensions of the tested coevaporates and plain ibuprofen in 5\% gum acacia were orally administered to different groups of adult albino mice $(20-28 \mathrm{~g})$ in a dose equal to $50 \mathrm{mg} / \mathrm{kg}$ of the drug and allowed to act for different time intervals : 2, 4, 6 and 8 hours. One group of mice was used for each time interval. Control animals were treated with $5 \%$ suspension of gum acacia. Following the specified period of time, the animals were intraperitonealy injected with $0.25 \mathrm{ml}$ of $0.02 \%$ solution of p-benzoquinone in water. The animals were observed for writhing during a period of one hour. The percentage protection against p-benzoquinone induced writhing was determined.

\section{7- Determination of the median lethal doses}

The median lethal doses $\left(\mathrm{LD}_{50}\right)$ and its $95 \%$ fiducial limits were calculated for each tested coevaporates and for plain ibuprofen. Groups of 
6 male adult albino mice (20-28 g), housed under the same conditions, were orally given graded doses of each formulation. The mortality was determined, 24 hours later, in each group of animals.

\section{8- Gastric ulcerogenic activity}

Twenty male albino rats weighing (200-260 g) were fasted over night. The rats were adminstered dose equal to $50 \mathrm{mg} / \mathrm{kg}$ of ibuprofen or its coevaporate granules, using an oral lavage needle. Ibuprofen or its coevaporates were given to the rats as suspension in $1 \mathrm{ml}$ of gum acacia. Control rats were given an equal volume of dispersion medium. The doses were repeated daily for seven days consequently. At 7 hours following the last dosing, the animals were killed. Stomach was excised, opened out along the lesser curvature and the contents were washed out with $0.9 \% \mathrm{w} / \mathrm{v}$ aqueous sodium chloride solution. Each stomach was stretched out and examined for the presence of ulcerations. Then, they were fixed in $10 \%$ formalin solution and the tissues were processed by the usual paraffin method, sectioned of $6 \mu \mathrm{m}$ and stained by hematoxylin and eosin $\operatorname{stain}^{10}$. The stained slides were examined microscopically and the best produced ones were selected for photography.

\section{RESULTS AND DISCUSSION}

The release profile of ibuprofen from granular coevaporates with different carriers is shown in (Fig. 1). The release rate of ibuprofen from granular ethylcellulose was higher than that of Eudragit and Aerosil at pH 7.2. In simulated gastric fluid $(\mathrm{pH} 1.5)$, the release rate of ibuprofen from granular Aerosil 200 was higher than those of the other carriers, followed by a stage of a constant rate. Table (1) compiled the results of the compression properties of coevaporate products with Avicel $\mathrm{pH} 102$. The compression properties were studied by determining the mean compression force consumed in the process of compression, the force transmission during tabletting ( $R$ value), the friability and the hardness. Table (1) shows that the three different forces produced tablets of uniform weight and similar good $R$ value. The force-hardness profile showed a linear relationship ${ }^{11}$ between compression force and the hardness of the tablets (Fig. 2) and illustrated the superiority of ibuprofen/ethylcellulose 20 coevaporate over the other forms. This is clear by least compression force required to compress $12.5 \mathrm{~kg}$ hardness tablets, good force distribution within the compacts ( $R$ value) and low friability.

The presence of Aerosil in the ibuprofen tablets, resulted in a decrease in hardness with a corresponding increase in the friability of the tablets. This result is in a good agreement with paracetmol and Aerosil ${ }^{12}$. It may be assumed that the incorporation of Aerosil with the drug in coevaporation weakened the interparticulate bonds between the drug particles similar to the effects of lubricants on tablet strength? Ibuprofen/Aerosil 200 formulae gave more friable tablets than ibuprofen/Aerosil R972 (Table 1). This may be due to that Aerosil 200, is more hygroscopic (moisture content $\%<1.5$ ) compared to Aerosil R972 (moisture content \% $<0.5)^{13}$.

The release profile of ibuprofen/ ethylcellulose 20 co-evaporate from tablets prepared at 3 different compression forces is demonstrated in (Fig. 3). The release rate of ibuprofen from tablets was decreased by increasing the compression forces. This may be due to the fact that increase in compression force may decrease the porosity of the tablets since, the porosity varies inversely with the logarithm of compression force ${ }^{14,15}$. This effect on tablet porosity may account for the lower drug released from tablets compressed at $13.9 \mathrm{KN}$. The maximum amount released at the end of 8 hours was only $59.8 \%$; while, at the lower compression force $6.06 \mathrm{KN}$, tablet released only $79.5 \%$ of the drug content at the end of 8 hours.

Wiseman and Federici ${ }^{16}$, concluded that the drug release from prolonged release tablets was controlled by hardness of the tablet and the ratio of the restraining matrix to the drug. Fig. 4 shows the influence of 3 different tabletting forces on the dissolution rates of ibuprofen/Eudragit RSPM coevaporate tablets. 
Table 1: $\quad$ Effect of different types of carriers (15\% w/w) with Avicel pH102 on the compression characteristics of ibuprofen tablets prepared by coevaporation.

\begin{tabular}{||l|c|c|c|c|c|c||}
\hline $\begin{array}{c}\text { Ibuprofen } \\
\text { with (15\%) } \\
\text { carrier }\end{array}$ & $\begin{array}{c}\text { Weight } \\
\text { of } \\
\text { tablet }\end{array}$ & $\begin{array}{c}\text { Mean } \\
\text { compression } \\
\text { force (KN) }\end{array}$ & $\mathrm{R}$ & $\begin{array}{c}\text { Hardness } \\
(\mathrm{kg})\end{array}$ & $\begin{array}{c}\text { Friability } \\
(\%)\end{array}$ & H.F.R. \\
\hline Ethyl & 440 & 13.94 & 0.91 & 12.50 & 0.68 & 18.38 \\
cellulose 20 & 440 & 9.61 & 0.87 & 9.25 & 0.84 & 11.01 \\
& 440 & 6.06 & 0.88 & 5.25 & 1.05 & 5.00 \\
Eudragit & 445 & 31.31 & 0.91 & 9.25 & 0.89 & 10.39 \\
RSPM & 440 & 17.81 & 0.91 & 7.45 & 0.99 & 7.53 \\
& 445 & 9.50 & 0.90 & 5.25 & 1.24 & 4.23 \\
Aerosil & 440 & 27.21 & 0.93 & 7.00 & 1.07 & 6.54 \\
200 & 440 & 15.34 & 0.92 & 5.55 & 1.65 & 3.36 \\
& 440 & 11.32 & 0.93 & 4.25 & 2.16 & 1.97 \\
Aerosil & 445 & 22.33 & 0.93 & 7.00 & 0.97 & 7.22 \\
R972 & 445 & 16.63 & 0.92 & 4.25 & 1.02 & 4.17 \\
& 445 & 13.86 & 0.93 & 2.75 & 1.30 & 2.12 \\
\hline
\end{tabular}

$R=$ force transmission index calculated by dividing the force at the level of the lower punch by the force at the level of the upper punch.

H.F.R. = hardness/friability ratio.

The drug in the formula is equivalent to $300 \mathrm{mg}$.

Avicel pH102 is $16 \%$ in the formula.

The diameter of the prepared tablets is $12 \mathrm{~mm}$.

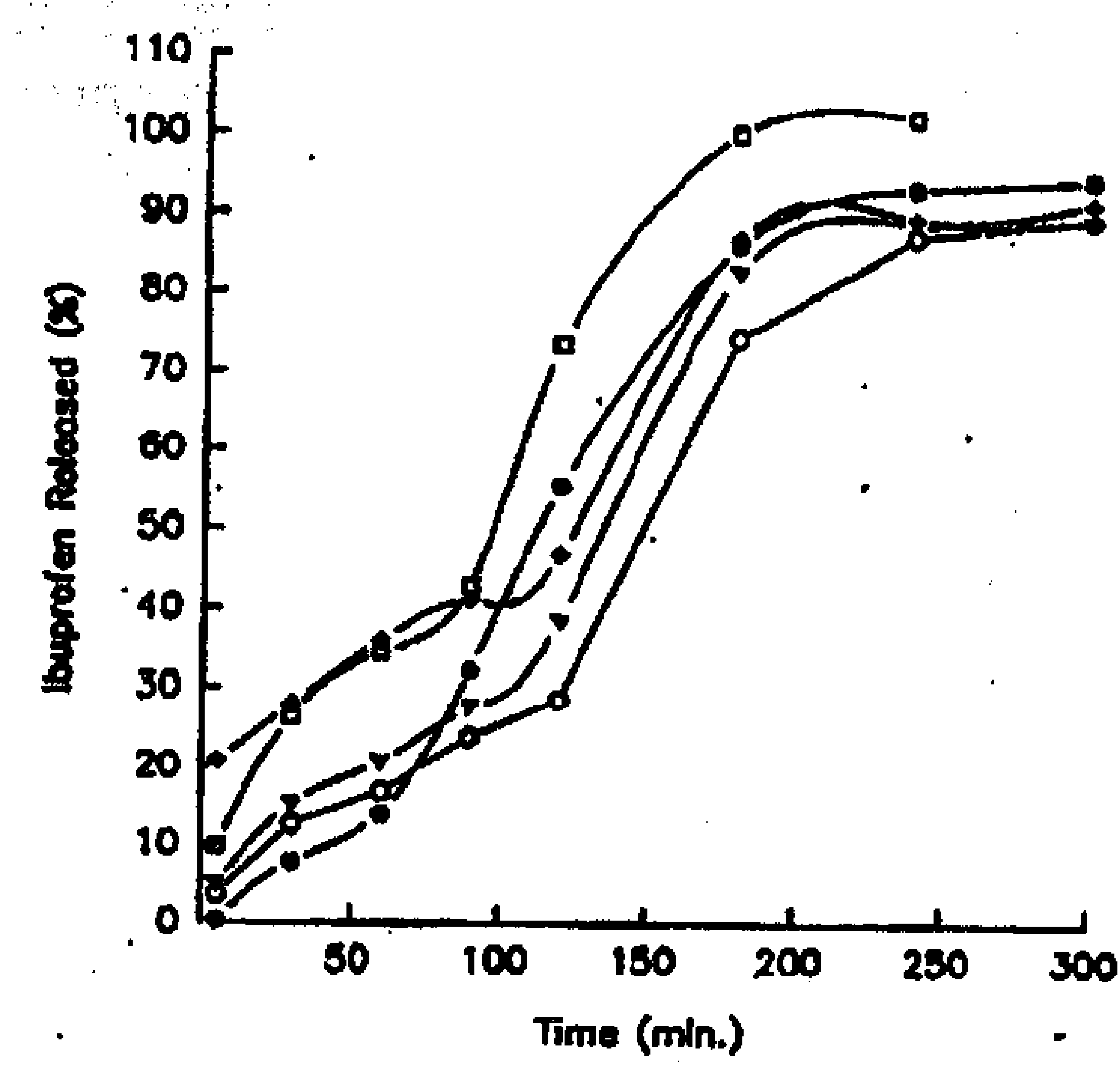

Fig. 1: Effect of different carriers $(15 \% \mathrm{w} / \mathrm{w})$ on the release of ibuprofen from its coevaporates granules.

Key: • Ethylcellulose; $\checkmark$ Eudragit; $\downarrow$ Aerosil 200; $\circ$ Aeroisl R972; $\square$ drug alone.

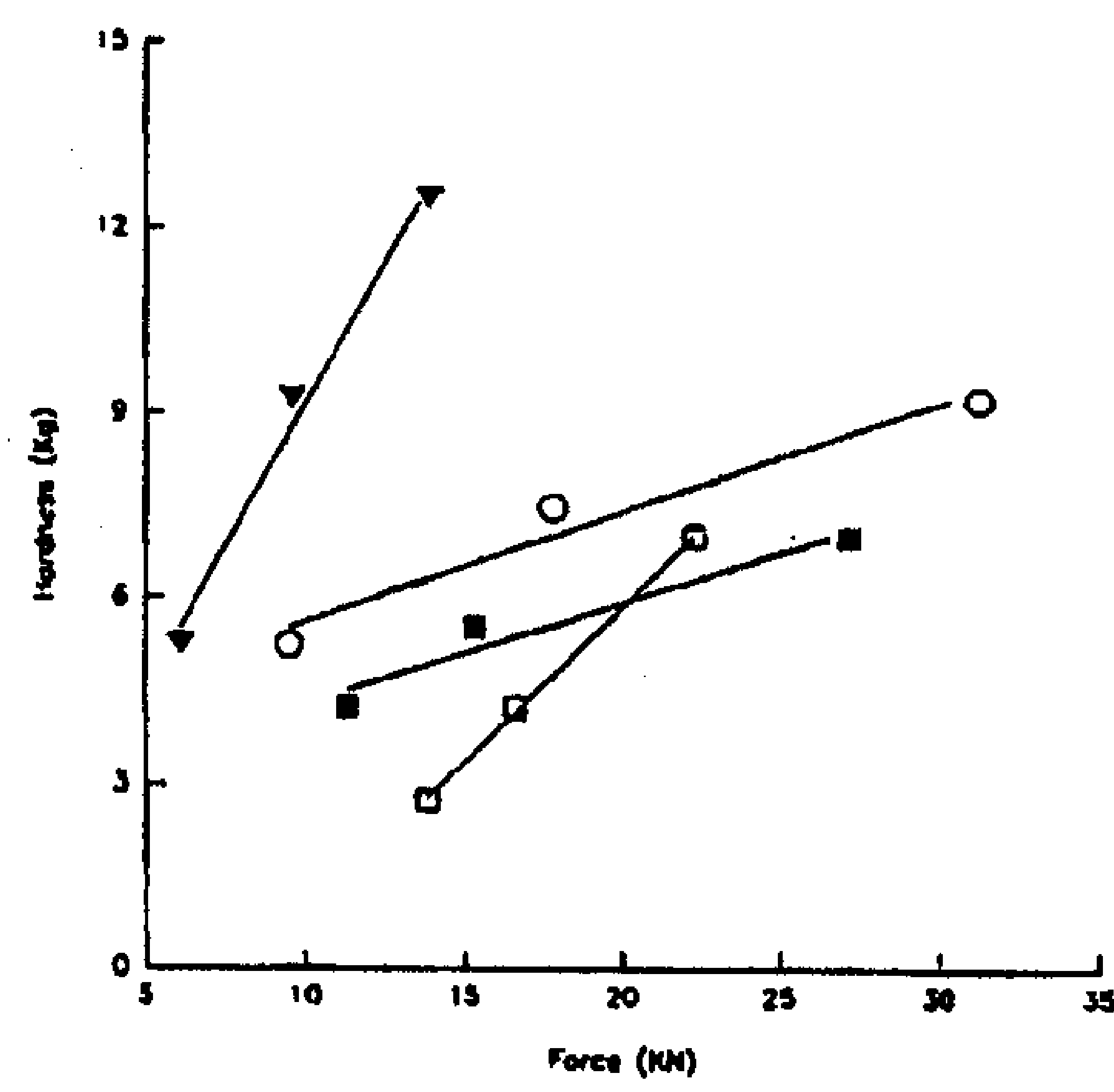

Fig. 2: Force-hardness profile of ibuprofen/ carriers coevaporates (15\%) with Avicel $\mathrm{pH} 102$ $(16 \%)$ and magnesium stearate $(1 \%)$.

Key: ○ Eudragit RSPM; $~$ Ethylecellulose 20; Aerosil 200; $\square$ Aerosil R972. 


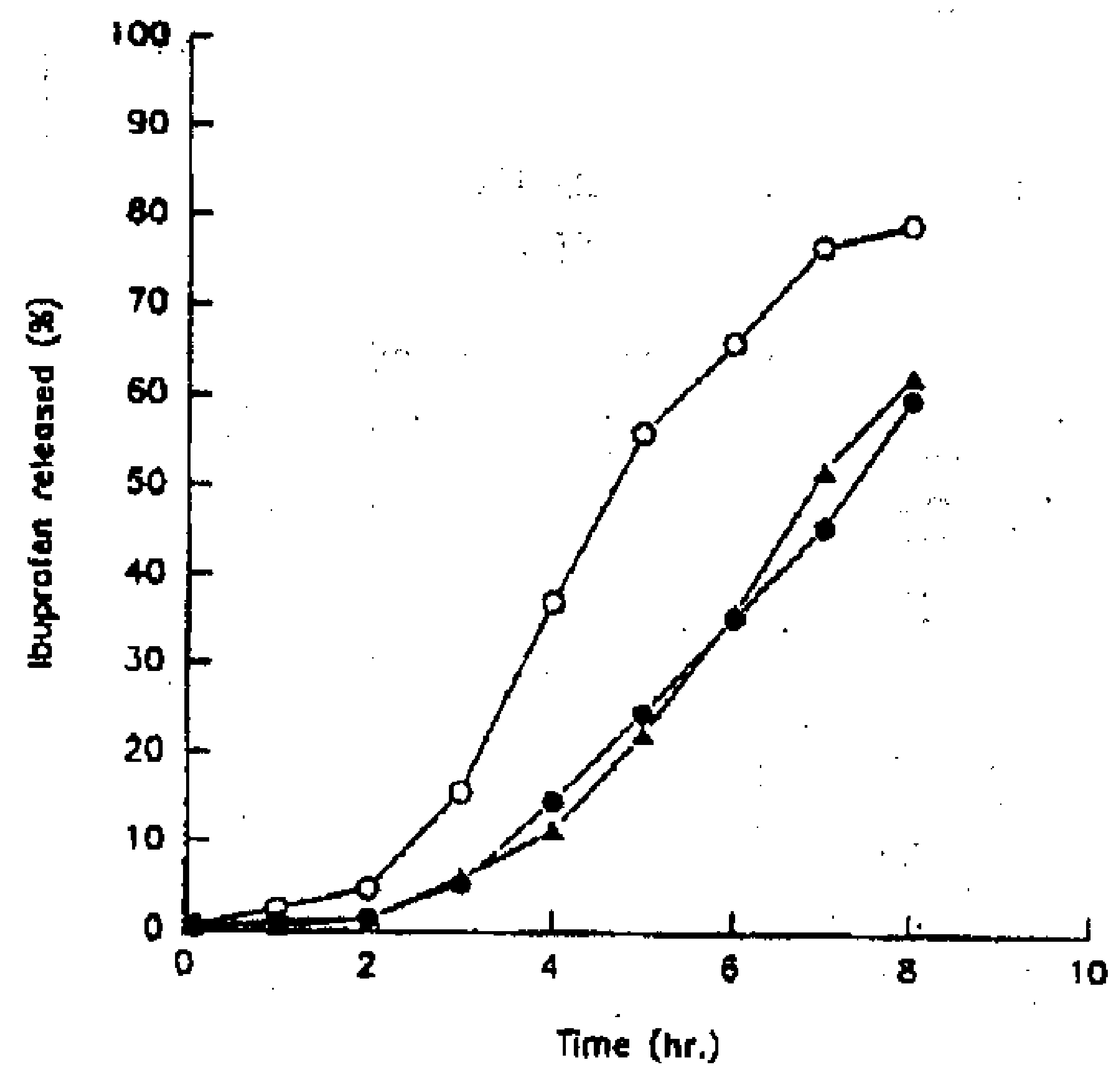

Fig. 3: Effect of different compressional forces on the release of ibuprofen/ethylcellulose 20 . coevaporates $(15 \%)$ from its tablets using shift dissolution method.

Key: $\bullet 13.94 \mathrm{KN} ; \triangle 9.61 \mathrm{KN} ; \circ 6.06 \mathrm{KN}$.

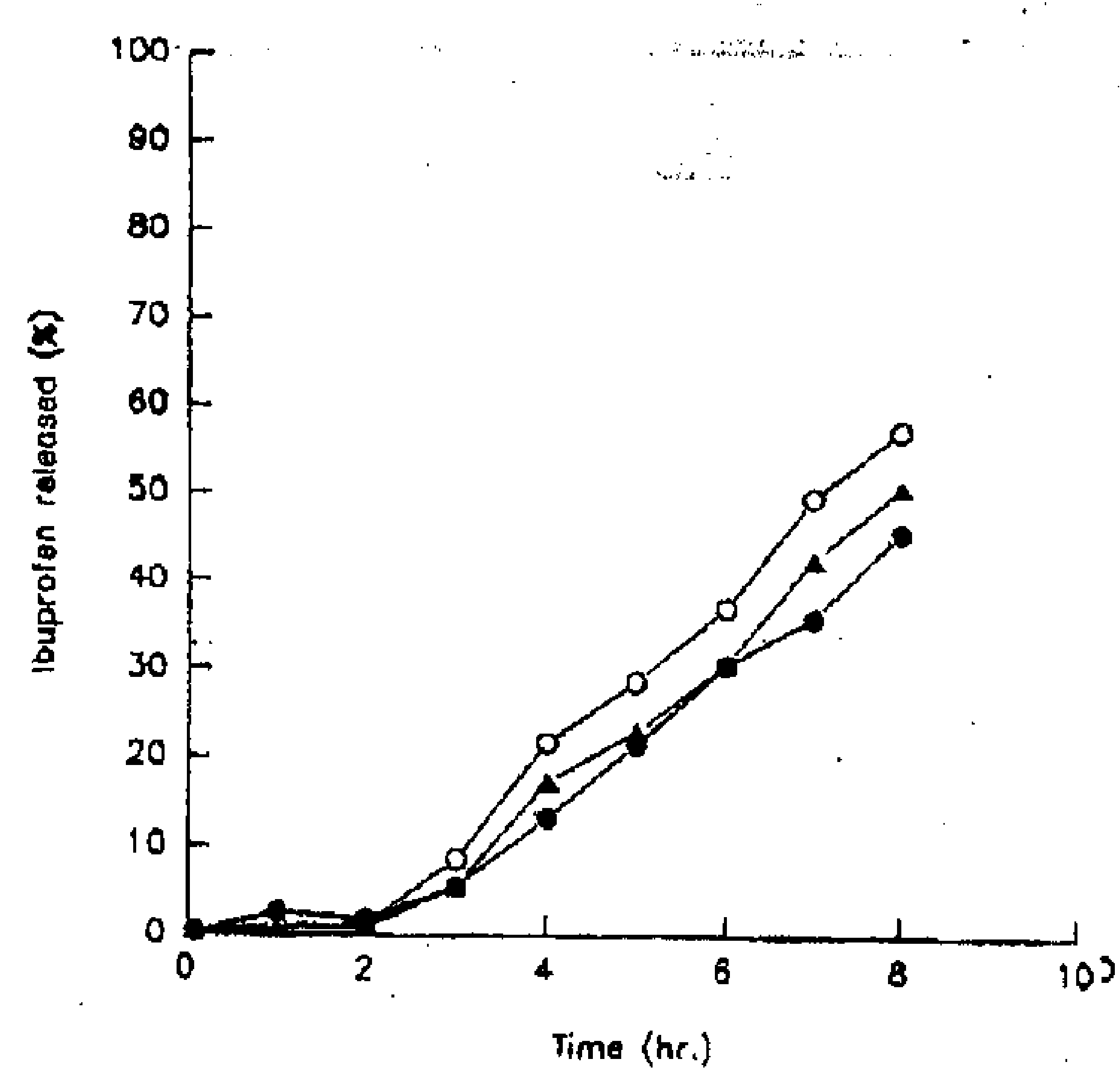

Fig. 4: Effect of differnet compressional forces on the release of ibuprofen/Eudragit RSPM coevaporates $(15 \%)$ from its tablets using shift dissolution medium.

Key: $\bullet 13.31 \mathrm{KN} ; \triangle 17.81 \mathrm{KN} ; \circ 9.50 \mathrm{KN}$.

The percent released after 8 hours ranged from $45 \%$ to $57 \%$ when compressed at $31.3 \mathrm{KN}$ (hardness $9.25 \mathrm{~kg}$ ) and at $9.5 \mathrm{KN}$ (hardness 5.25 $\mathrm{kg}$ ) respectively. In general, this effect could be explained on the basis of the poor aqueous solubility of ibuprofen ${ }^{17}$ and the poor surface wettability of Eudragit RSPM ${ }^{18}$.

Ethylcellulose allows a selective and greater release at each $\mathrm{pH}$ than Eudragit. This result is in a good agreement with the findings of Zecchi et al. ${ }^{19}$.

Release patterns of ibuprofen tablets prepared from ibuprofen/Aerosil 200 and ibuprofen/Aerosil R972 coevaporates tablets compressed at 3 different forces are shown in (Figs. 5,6). The tablets prepared from the coevaporates with Aerosil exhibited prolonged release pattern like a matrix type especially at higher forces. This observation may be ascribed to its gel-forming ability ${ }^{20}$. Since, the gel would create a viscous barrier between the granules and the water.

The release behavior of ibuprofen tablets prepared from the coevaporates with Aerosil, was relatively higher than that prepared with ethylcellulose 20 and Eudragit RSPM under the same condition. These results can be explained on the basis that the Aerosil may be behaving as a disintegrant by absorbing water. This behaviour of Aerosil may be complementing the disintegrant effect of the Avicel ${ }^{12}$. This finding also might be interpreted in terms of hydrophilic property of colloid silica contained in the product, promoting penetration of the release medium into the tablet. The release of the drug from the directly compressed coevaporates was found to be much slower than for the granular coevaporates (Fig. 1,3-6). The difference in the release rate is attributed to the compressed nature of the tabletted coevaporates resulting in a greatly reduced surface area available for drug release.

By this technique and by using the above mentioned carriers, the release rate of ibuprofen is very low at simulated gastric fluid ( $\mathrm{pH} 1.2)$ and this will be expected to protect the stomach from the side effects of the drug.

In earlier reports ${ }^{21-23}$, it was stated that the compression force of the tablet and hardness did not show marked differences in release characteristics as evaluated by an in vitro method.

Several other reports have been presented on the effect of the compression force on drug release from matrix tablets ${ }^{24,25}$. The release curves obtained are shown in (Figs. 3-6). 


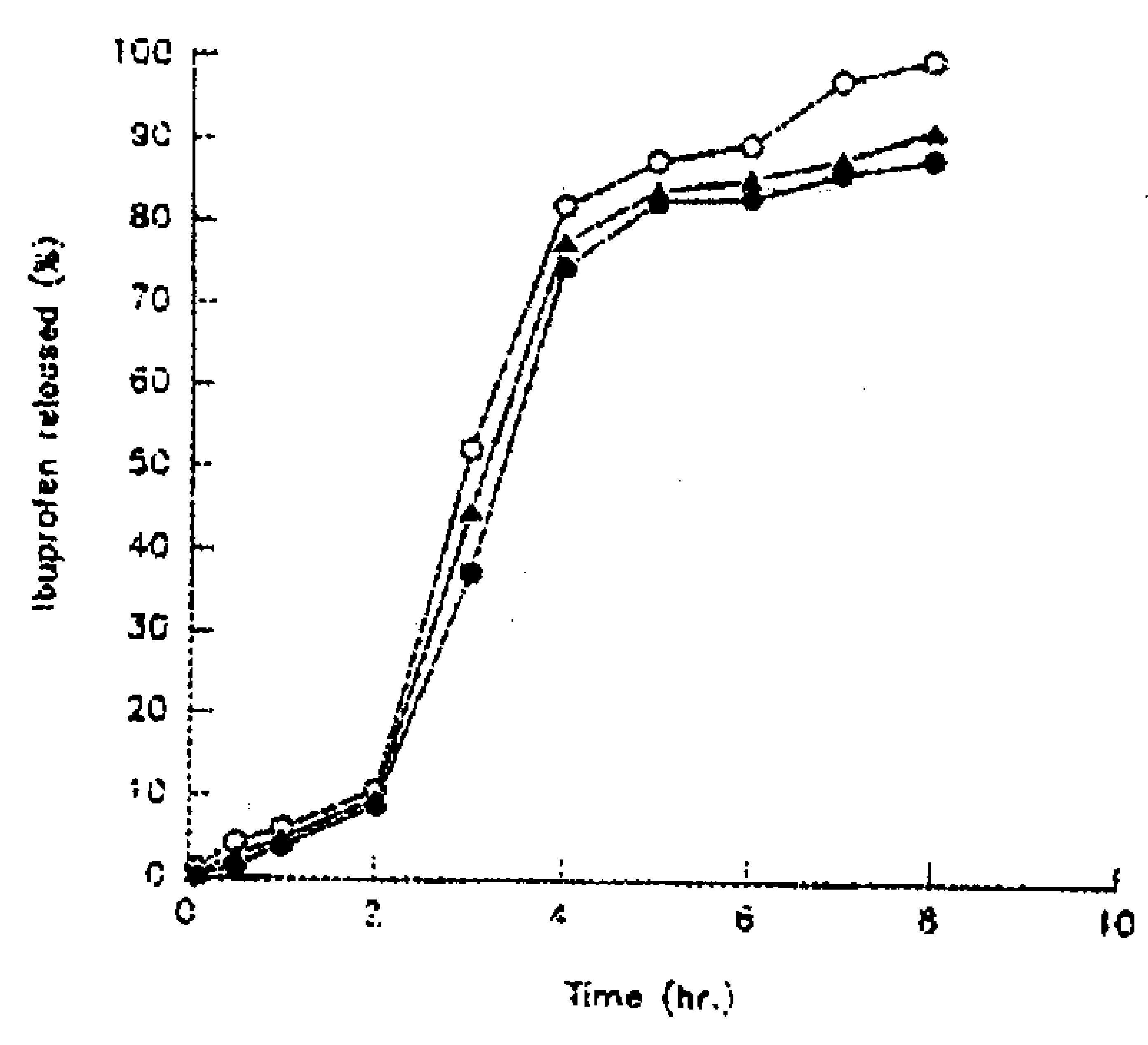

Fig. 5: Effect of different compressional forces on the release of ibuprofen/Aerosil 200 coevaporates (15\%) from its tablets using shift dissolution medium.

Key: $\bullet 27.21 \mathrm{KN} ; \triangle 15.34 \mathrm{KN}$; $\circ 11.32 \mathrm{KN}$.

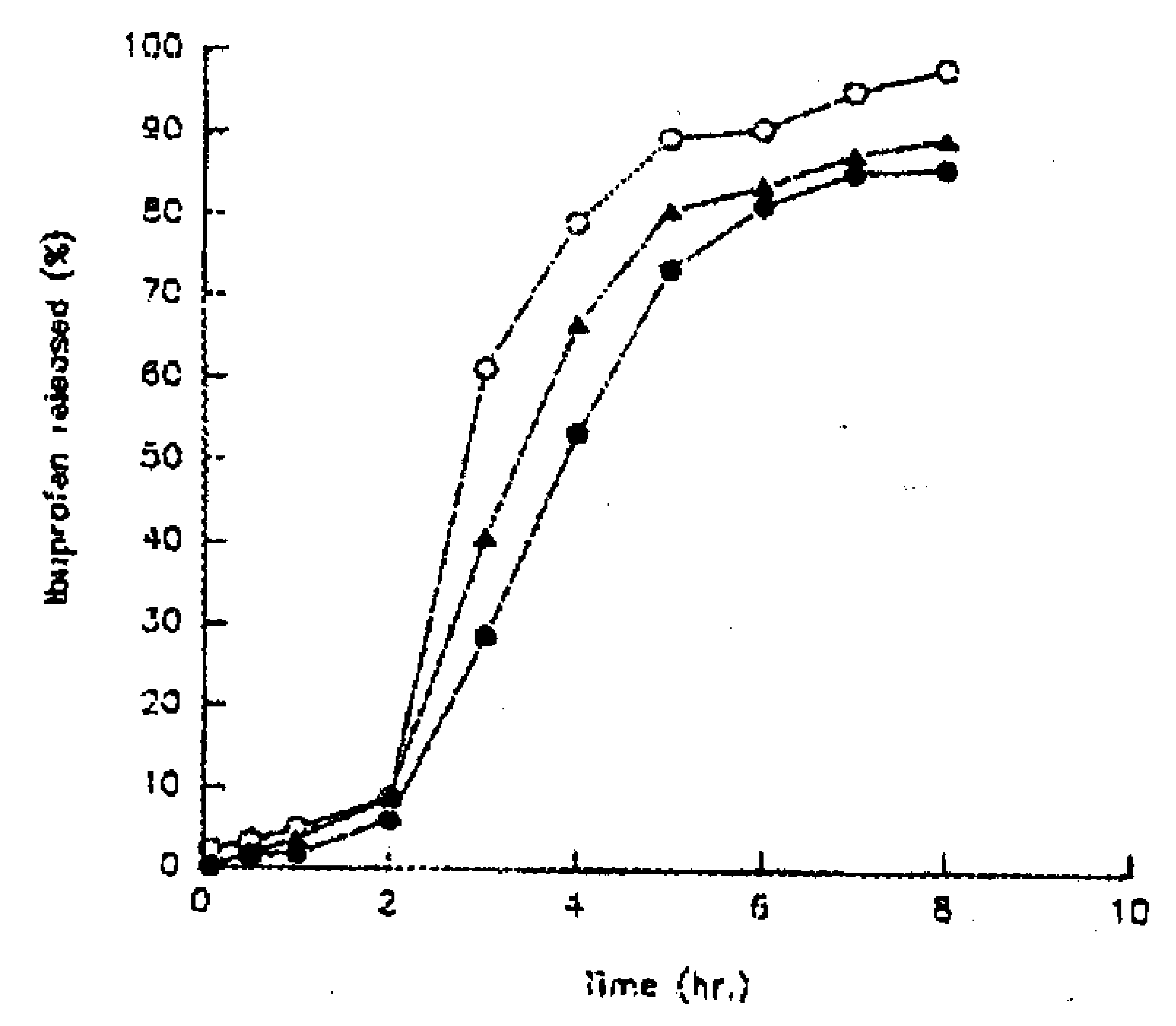

Fig. 6: Effect of different compressional forces on the release of ibuprofen/Aerosil R972 coevaporates $(15 \%)$ from its tablets using shift dissolution method.

Key: $\bullet 22.33 \mathrm{KN} ; \triangle 16.63 \mathrm{KN}$; $13.86 \mathrm{KN}$.

Increasing the compression force lead to decrease of the release rate of the drug. In a more quantitative fashion, the release rate constant $\left(\mathrm{K}, \mathrm{hr}^{-1}\right)$ would have to be a function of hardness $(\mathrm{H})$. To establish the function that could describe this dependence, the effect of hardness will be examined. It is conventional to fit release data to one of several types of functions ${ }^{26}$. The plotting should follow this equation

$$
\operatorname{Ln}\left(\mathrm{m} / \mathrm{m}_{\mathrm{o}}\right)=-\mathrm{Kt}+\mathrm{a} \ldots \ldots
$$

where $\mathbf{m}_{\mathrm{o}}$ is the amount of drug present in tablet, $m$ is the amount not dissolved, $K$ is the dissolution constant and $t$ is the time. Table (2), shows the least-squares fit parameters for all the preparations. From the correlation coefficients the empirical choice of Eq. 1, is well justified.

It was mentioned earlier that $\mathrm{K}$ decreases with increasing hardness $H$, and inspection of Table (2) leads to the plausibility of a relation of the type :

$$
\operatorname{Ln} K=\alpha H+\beta \ldots \ldots \ldots
$$

The least-square values for $K$ for all the preparations in Table 2, have been treated according to Eq. 2, and for each polymer (i), the least square fit parameters $\beta_{i}$ and $\alpha_{i}$ are listed in Table (3). A dimensionaless plot, as described by Brossard $e t a l{ }^{25}$ and Cruaud et $a l .{ }^{27}$, is shown in Fig. 7, the ordinate values are the individual values of $Y=\operatorname{Ln} K_{1}-\beta$, and the abscissa values are $X=\alpha_{i} H_{i}$, and since according to Eq.2.

$$
\left(\operatorname{Ln} \mathrm{K}_{\mathrm{i}}\right)-\beta_{\mathrm{i}}=\alpha_{\mathrm{i}} \mathrm{H}
$$

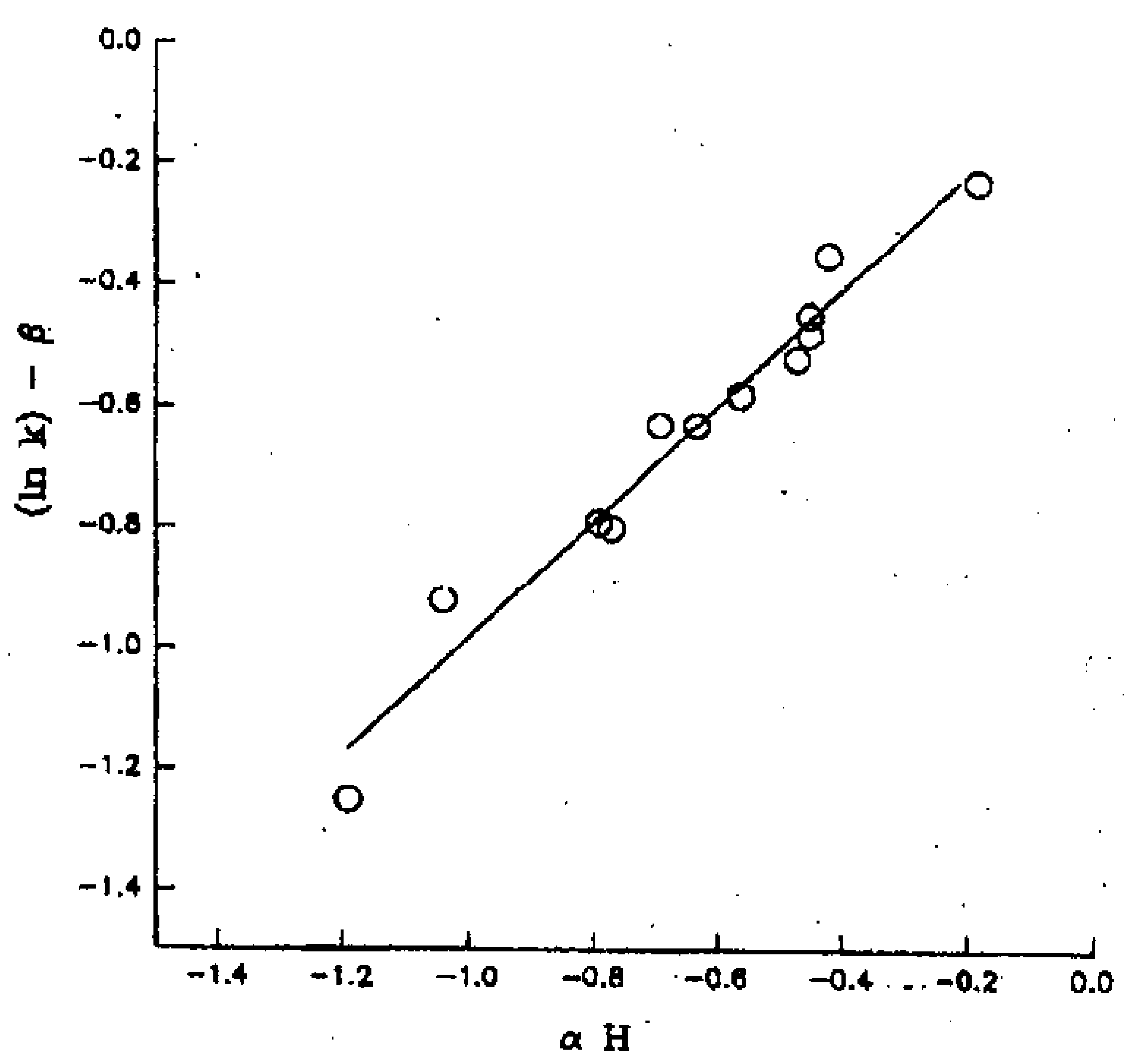

Fig. 7: Consistency diagram for Eq. 2 (Eq. 3). If Eq. 2 is a reasonable fit, then $Y=X$, where $X=\alpha$ and $Y=\ln K-B$. The least squares fit of the line is $\mathrm{Y}=1.004 \mathrm{x}=$ 0.002 , i.e. the slope is close to unity, the intercept is close to zero, and the equation is close to $\mathrm{Y}=\mathrm{X}$. 
Table 2: Least-squares fit values for all release data treated according to equation 1.

\begin{tabular}{|l|c|c|c|c||}
\hline $\begin{array}{c}\text { Type of the } \\
\text { carrier }\end{array}$ & $\begin{array}{c}\text { Hardness } \\
\mathrm{Kg}\end{array}$ & $\begin{array}{c}\text { Correlation } \\
\text { coefficient } \\
\mathrm{r}\end{array}$ & $\begin{array}{c}\text { Intercept } \\
\text { (a) }\end{array}$ & $\begin{array}{c}\text { Negative } \\
\text { slope } \\
\mathrm{K}\end{array}$ \\
\hline Eudragit & 5.25 & 0.975 & 0.161 & 0.111 \\
RSPM & 7.45 & 0.968 & 0.144 & 0.090 \\
& 9.25 & 0.972 & 0.120 & 0.080 \\
Ethyl- & 5.25 & 0.980 & 0.296 & 0.218 \\
cellulose 20 & 9.35 & 0.935 & 0.221 & 0.124 \\
& 12.50 & 0.951 & 0.179 & 0.107 \\
Aerosil & & & & \\
200 & 4.25 & 0.975 & 0.402 & 0.465 \\
& 5.55 & 0.962 & 0.291 & 0.368 \\
Aerosil & 7.00 & 0.954 & 0.279 & 0.339 \\
R972 & 2.75 & 0.979 & 0.580 & 0.596 \\
& 4.25 & 0.973 & 0.502 & 0.469 \\
\hline
\end{tabular}

Table 3: Least-squares fit parameters values according to equation 2.

\begin{tabular}{||l|c|c|c|}
\hline \multicolumn{1}{|c|}{ Carrier } & $\alpha$ & $B$ & $\begin{array}{c}\text { Correlation } \\
\text { coefficient, r }\end{array}$ \\
\hline Eudragit RSPM & -0.085 & -1.75 & 0.999 \\
Ethylcellulose 20 & -0.099 & -1.05 & 0.965 \\
Aerosil 200 & -0.114 & -0.312 & 0.955 \\
Aerosil R972 & 0.083 & -0.334 & 0.947 \\
\hline
\end{tabular}

Line with unity slope and zero intercept should follow. Figure 7, indicates that this is the case, showing that Eq. 2, is a reasonable choice of the function representing the dependence of $\mathrm{K}$ on $\mathrm{H}$, and all values for all the preparations are included.

\section{Kinetics of ibuprofen release}

In order to explore the mechanism of drug release from this system, the experimental data were treated on the basis of the diffusion controlled, first order and zero order kinetic models. Table (4) demonstrates the comparison between the linearizations of release rate data by these three models. The zero order equation gave consistently higher values for the correlation coefficient than did the diffusion and first order equations

In case of Aerosil, the correlation coefficients of these three models are similar. For more confirmation, first order was adopted, the rate $d Q / d t$ is plotted against the $Q$, where $Q$ is the total amount of drug released.

$$
\mathrm{dQ} / \mathrm{dt}=\mathrm{KA}-\mathrm{K} \mathbf{Q}
$$

Linearity was not obtained in this case. This indicate that the process is not first order. 
Table 4: $\quad$ Summary of power function fits for compressed ibuprofen tablets in shift change dissolution method.

\begin{tabular}{||c|c|c|c|c|c|c|}
\hline $\begin{array}{c}\text { Type of carrier/ } \\
\text { forces (KN) }\end{array}$ & $\mathrm{k}_{\mathrm{z}}$ & $\mathrm{r}_{\mathrm{z}}$ & $\mathrm{k}_{\mathrm{f}}$ & $\mathrm{r}_{\mathrm{f}}$ & $\mathrm{k}_{\mathrm{h}}$ & $\mathrm{r}_{\mathrm{h}}$ \\
\hline Ethylcellulose & & & & & & \\
$(13.94)$ & 23.99 & 0.974 & -0.046 & -0.951 & 67.48 & 0.875 \\
$(9.61)$ & 26.92 & 0.963 & -0.054 & -0.936 & 74.96 & 0.856 \\
$(\mathbf{6 . 0 6 )}$ & 37.66 & 0.981 & -0.095 & -0.980 & 111.25 & 0.926 \\
& & & & & & \\
Eudragit RSPM & & & & & & \\
$(31.31)$ & 18.65 & 0.982 & -0.034 & -0.972 & 53.23 & 0.895 \\
$(17.81)$ & 21.00 & 0.981 & -0.040 & -0.968 & 59.67 & 0.891 \\
$(9.06)$ & 23.82 & 0.988 & -0.048 & -0.975 & 68.49 & 0.907 \\
& & & & & & \\
Aerosil 200 & & & & & & \\
$(27.21)$ & 51.73 & 0.974 & -0.169 & -0.958 & 150.76 & 0.933 \\
$(15.34)$ & 52.06 & 0.971 & -0.194 & -0.965 & 157.83 & 0.945 \\
$(11.32)$ & 54.04 & 0.973 & -0.246 & -0.972 & 163.01 & 0.937 \\
& & & & & & \\
Aerosil R972 & & & & & & \\
$(22.33)$ & 46.95 & 0.950 & -0.141 & -0.950 & 140.48 & 0.934 \\
$(16.63)$ & 47.91 & 0.959 & -0.153 & -0.958 & 144.08 & 0.939 \\
$(13.86)$ & 50.16 & 0.960 & -0.193 & -0.970 & 151.13 & 0.942 \\
\hline
\end{tabular}

$\mathrm{K}_{\mathrm{z}}\left(\mathrm{mg} \cdot \mathrm{min}^{-1}\right), \mathbf{k}_{\mathrm{f}}\left(\mathrm{min}^{-1}\right), \mathrm{k}_{\mathrm{h}}\left(\mathrm{mg} \cdot \mathrm{cm}^{-2} \cdot \mathrm{min}^{1 / 2}\right)$ are release rate constants according to the zero, first-order and Higuchi's equation respectively.

$r_{z}, r_{f}$ and $r_{h}$ are correlation coefficients.

Korsmeyer et al. ${ }^{28}$ derived a simple relationship, Eq. 5 which may be used to describe drug release from polymeric systems, in which the release of the drug follows one of the three mechanisms listed in the following Table.

$$
\mathbf{M}_{\mathbf{t}} / \mathbf{M}_{\infty}=\mathrm{K} \mathrm{t}^{\mathrm{n}} \quad \ldots \ldots \ldots \ldots
$$

\section{Analysis of diffustional release mechanisms ${ }^{28}$}

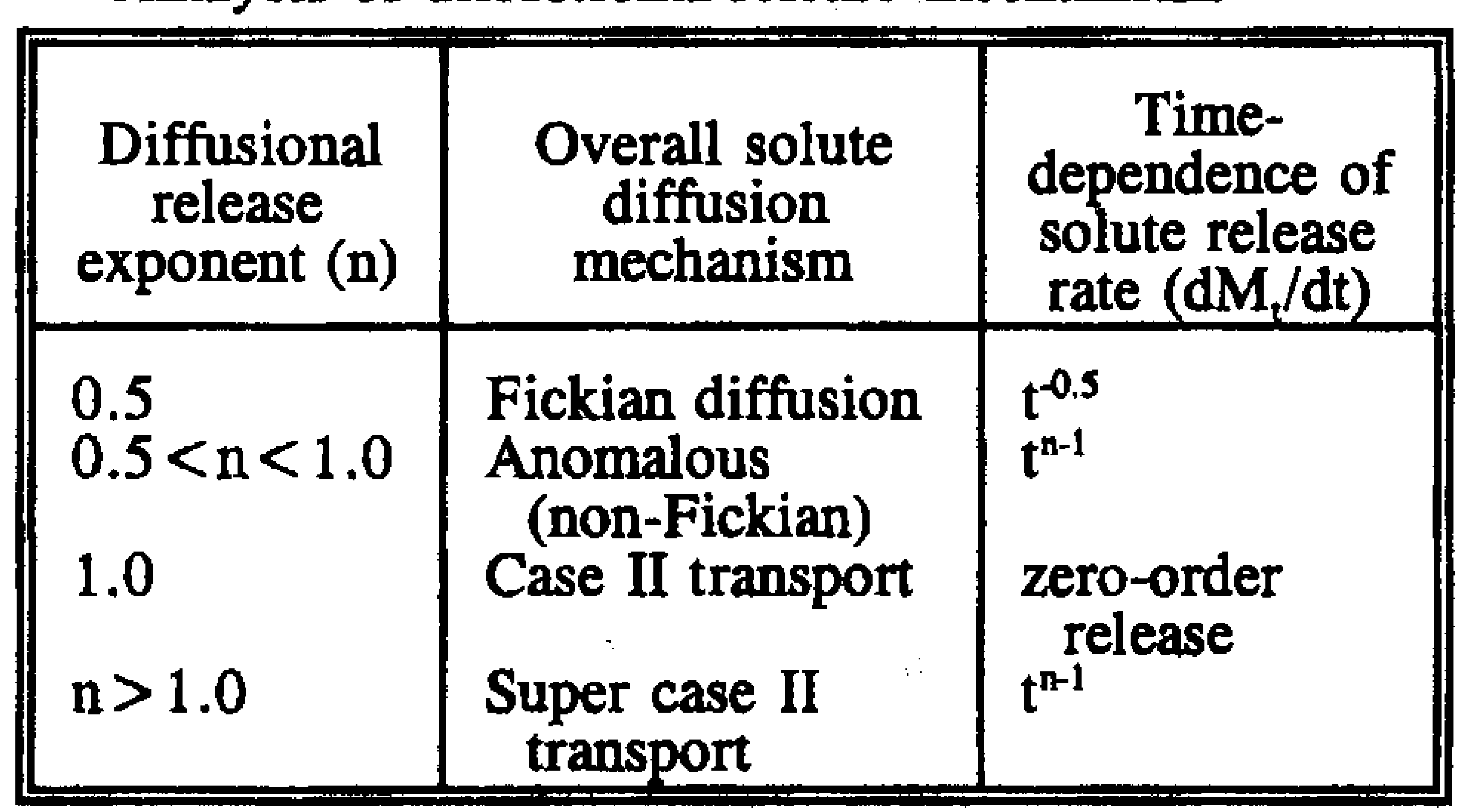

where $M_{1} / M_{\infty}$ is the fractional release of the drug, $t$ is the release time, $K$ is a constant incorporating structural and geometric characteristic of the release device and $n$ is the release exponent indicative of the mechanism of release. For instance $n=0.5$ for diffusion mchanism and $n=1.0$ for zero order release. Alternatively

$$
\log M_{t} / M_{\infty}=\log K+n \log t .
$$

Table 5, gives the values of $\mathrm{n}$ obtained by regression analysis for ibuprofen/Aerosil tablet formulations. The values of $\mathrm{n}$ fall within the range of 1.0-1.5, indicating that the drug release from the Aerosil matrix is of the non- Fickian and super case II transport type $e^{28-30}$. This kind of release corresponds to a more predictable type of swelling-controlled system in which the rate of solvent uptake into a carrier is largely 
determined by the rate of swelling and relaxation of the carrier ${ }^{30}$. For tablets containing Aerosil 200 or Aerosil R972 compressed at $11.32 \mathrm{KN}$ and $13.86 \mathrm{KN}$ respectively, values of $\mathrm{n}$ were closer to 1.0 , indicating that the tablets behave as a zero-order release system. Ibuprofen is released from these matrices by a zero-order release rate, which seems to be controlled by the swelling relaxation of the carrier.

Table 5: Fitting of solute release data of ibuprofen tablets to equation 6 .

\begin{tabular}{||c|c|c|}
\hline $\begin{array}{c}\text { System/force } \\
(\mathrm{KN})\end{array}$ & $\begin{array}{c}\text { Exponent } \\
(\mathrm{n})\end{array}$ & $\mathbf{r}$ \\
\hline Aerosil 200 & & \\
$(11.32)$ & 1.1 & 0.967 \\
$(15.34)$ & 1.3 & 0.981 \\
$(27.21)$ & 1.5 & 0.990 \\
& & \\
Aerosil R972 & & \\
$(13.86)$ & 1.0 & 0.980 \\
$(16.63)$ & 1.2 & 0.982 \\
$(22.33)$ & 1.4 & 0.989 \\
\hline
\end{tabular}

No change in the physical properties of the ibuprofen tablets occurred after 6 months under the storage conditions. Only the colour of the test samples, intially off white-pale yellow, progressively deepened with increasing storage time at elevated temperature $\left(45^{\circ} \mathrm{C}\right)$ and humidity $(40 \% \mathrm{RH})$. The changes in colour of the test tablets when stored at these conditions are considered to arise from changes in the material characteristics of the polymer rather than those of the drug, and these effects were confirmed by DSC.

No marked changes were found in the dissolution rate of ibuprofen from tablets aged for 6 months at temperature $45^{\circ} \mathrm{C}$ and $40 \% \mathrm{RH}$. The stability indicate that ibuprofen tablets prepared by coevaporation possess suitable stability for use as pharmaceutical formulations.

\section{Antiinflammatory activity}

Figure 8, presents the antiinflammatory activity of ibuprofen and its coevaporates at different time intervals against inflammation induced by histamine in rats. This inflammation means the disturbance in the capillary permeability induced by intradermal injection of

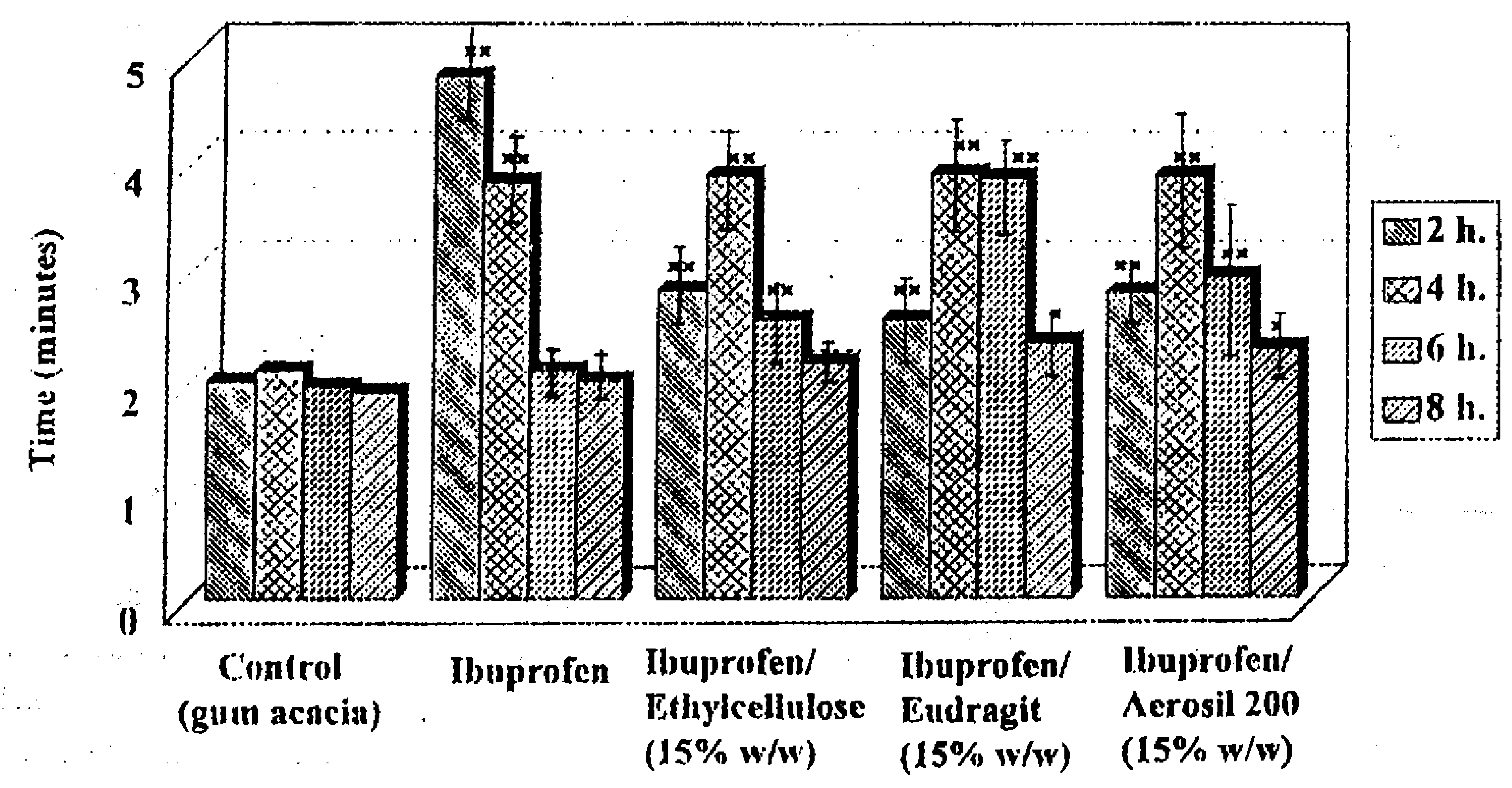

Fig. 8: Anti-inflammatory activity of ibuprofen and the investigated formulations after $2 \mathrm{~h}, 4 \mathrm{~h}, 6 \mathrm{~h}$ and 8 hours of oral administration against inflammation induced by histamine in rats. Values are mean of 6 experiments \pm standard error.

* Significant difference from control values at $P<0.05 . * *$ Significant difference from control values at $P<0.01$. 
histamine. The antiinflammatory activity can be calculated as the time taken for the appearance of a blue colour around the site of histamine injection following an intravenous injection of the trypan-blue dye.

It is evident from the figure that in animals that have been treated with $5 \%$ solution of gum acacia, the appearance of the blue colour took place within time ranging from 1.9 to 2.1 minutes at different time intervals. Ibuprofen was found to increase significantly the time of appearance of the blue colour at 2 and 4 hours after oral administration to rats. The maximal antiinflammatory effect of ibuprofen appeared after 2 hours. The oral treatment of rats with ibuprofen/ethylcellulose increased significantly the time of appearance of the blue colour after 2,4 and 6 hours. The maximal antiinflammatory effect of this formulation appeared after 4 hours. Ibuprofen/Eudragit and ibuprofen/Aerosil 200 coevaporates were able to increase significantly the time of appearance of the blue colour at 2 , 4,6 and 8 hours after their oral administration to rats. The maximal anti-inflammatory effect of ibuprofen/Eudragit appeared after 4 hours, while that of ibuprofen/Aerosil 200 appeared nearly after 4 and 6 hours.

\section{Analgesic activity}

The study of the analgesic activity of ibuprofen and its coevaporates revealed that all the tested formulations have the ability to protect the mice from thermal pain (Table 6). The hot plate latencies were found to be increased when these formulations and plain ibuprofen were administered orally into albino mice.

Control mice receiving a suspension of $5 \%$ gum acacia were found to have a reaction time ranging from 6.01 to 6.34 seconds at different time intervals. Ibuprofen was found to increase significantly the reaction time after 2 and 4 hours of its oral administration to mice. The maximal analgesic effect of ibuprofen appeared after 2 hours. The oral treatment of mice with ibuprofen/ethylcellulose, ibuprofen/Eudragit and ibuprofen/Aerosil 200 increased significantly the reaction time after 2, 4, 6 and 8 hours. The maximal analgesic effect of ibuprofen/ ethylcellulose and ibuprofen/Aerosil appeared after 4 hours. Ibuprofen/Eudragit exhibited its maximal analgesic effect nearly after 4 and 6 hours of its administration to mice.

Also, the investigated formulations were found to have the ability to increase the duration of the analgesic activity of ibuprofen against chemical pain induced by p-benzoquinone in mice (Table 7). The percentage protection against p-benzoquinone induced writhing were found to be increased at different time intervals when the coevaporates were administered orally to albino mice.

Control animals receiving a suspension of $5 \%$ gum acacia did not show any protection against writhing produced by p-benzoquinone. Ibuprofen elicited protection against p-benzoquinone induced writhing after 2, 4 and 6 hours of its oral administration to mice. Mice treated orally with ibuprofen/ethylcellulose, ibuprofen/Eudragit and ibuprofen/ Aerosil 200 displayed protection against writhing induced by p-benzoquinone for 8 hours. Ibuprofen/Eudragit elicited the greatest degree of protection after 4 and 6 hours, while ibuprofen/ethylcellulose and ibuprofen/Aerosil elicited the protection after 4 hours of oral administration to mice.

\section{Acute toxicity of the tested coevaporates}

Results in Table 8 illustrate that all the tested formulations have higher oral median lethal doses $\left(\mathrm{LD}_{50}\right)$ in mice when compared with ibuprofen. Ibuprofen/Eudragit was found to be the least toxic followed by Ibuprofen/Aerosil and then ibuprofen/ethylcellulose.

\section{Gastric ulcerogenic activity}

Histological examination of the control surface mucosa of the stomach fundus showed that the mucosa is regular and linned with epithelial cells (Fig. 9). The epithelial cells are tall columnar and contain an oval nuclei. The fundic glands are occupied all the thickness of the mucosa laminapropria and are arranged in perpendicular manner to the surface epithelium. The mucous neck cell are observed very near to the epithelial cells. They are cuboidal with flat nuclei. The oxynetic cells are pyramidal acidophilic. The last layer of the mucosa is the muscularis mucosa. In control group the $\mathrm{H}$ \& $\mathrm{E}$ staining sections are normal in every instance. 
Table 6: $\quad$ Analgesic activity of ibuprofen and the tested coevaporates as measured by hot plate method in mice.

\begin{tabular}{|c|c|c|c|c|c||}
\hline \multirow{2}{*}{$\begin{array}{c}\text { Time after } \\
\text { oral } \\
\text { administrat- } \\
\text { ion (hours) }\end{array}$} & $\begin{array}{c}\text { Control } \\
\text { (gum acacia) }\end{array}$ & Ibuprofen & $\begin{array}{c}\text { Ibuprofen/ } \\
\text { ethylcellulose }\end{array}$ & $\begin{array}{c}\text { Ibuprofen/ } \\
\text { Eudragit }\end{array}$ & $\begin{array}{c}\text { Ibuprofen/ } \\
\text { Aerosil 200 }\end{array}$ \\
\cline { 2 - 6 } & $6.32 \pm 0.11$ & $15.82^{* *} \pm 0.21$ & $11.25^{* *} \pm 0.18$ & $9.95^{* *} \pm 0.20$ & $11.15^{* *} \pm 0.18$ \\
2 & $6.01 \pm 0.13$ & $12.80^{* *} \pm 0.19$ & $12.88^{* * *} \pm 0.22$ & $13.10^{* *} \pm 0.15$ & $12.91^{* *} \pm 0.12$ \\
4 & $6.28 \pm 0.16$ & $7.21 \pm 0.15$ & $9.85^{* *} \pm 0.21$ & $13.06^{* *} \pm 0.19$ & $11.30^{* *} \pm 0.14$ \\
6 & $6.34 \pm 0.12$ & $6.42 \pm 0.17$ & $7.85^{* *} \pm 0.18$ & $8.75^{* *} \pm 0.12$ & $8.50^{* *} \pm 0.09$ \\
8 & &
\end{tabular}

- Values are mean of 6 experiments \pm standard error.

* Significant difference $(P<0.05)$ by student's t-test compared with the control.

** Significant difference $(P<0.01)$ by student's $t$-test compared with the control.

Table 7: Analgesic activity of ibuprofen and the tested coevaporates aginst p-benzoquinone induced writhing in mice.

\begin{tabular}{||l|c|c|c|c||}
\hline \multirow{2}{*}{ Formula } & \multicolumn{4}{|c|}{ Time after oral administration (hours) } \\
\cline { 2 - 5 } & 2 & 4 & 6 & 8 \\
\hline Control & 0 & 0 & 0 & 0 \\
Ibuprofen & 80 & 60 & 10 & 0 \\
Ibuprofen/ethylcellulose & 40 & 60 & 30 & 10 \\
Ibuprofen/Eudragit & 30 & 60 & 60 & 20 \\
Ibuprofen/Aerosil 200 & 40 & 60 & 40 & 20 \\
\hline
\end{tabular}

- Data represent the percentage protection against p-benzoquinone induced writhing.

- Groups of 10 mice were used for each tested time interval.

Table 8: The oral median lethal dose $\left(\mathrm{LD}_{50}\right)$ of ibuprofen and its coevaporates in mice.

\begin{tabular}{|l|c|}
\hline \multicolumn{1}{|c|}{ Formula } & $\begin{array}{c}\mathrm{LD}_{s 0}(\mathrm{mg} / \mathrm{kg}) \text { and its } \\
\text { fiducial limits of error }\end{array}$ \\
\hline Ibuprofen & $1250 \pm 419.35$ \\
Ibuprofen/ethylcellulose & $1450 \pm 424.19$ \\
Ibuprofen/Eudragit & $1850 \pm 512.30$ \\
Ibuprofen/Aerosil 200 & $1750 \pm 492.80$ \\
\hline
\end{tabular}




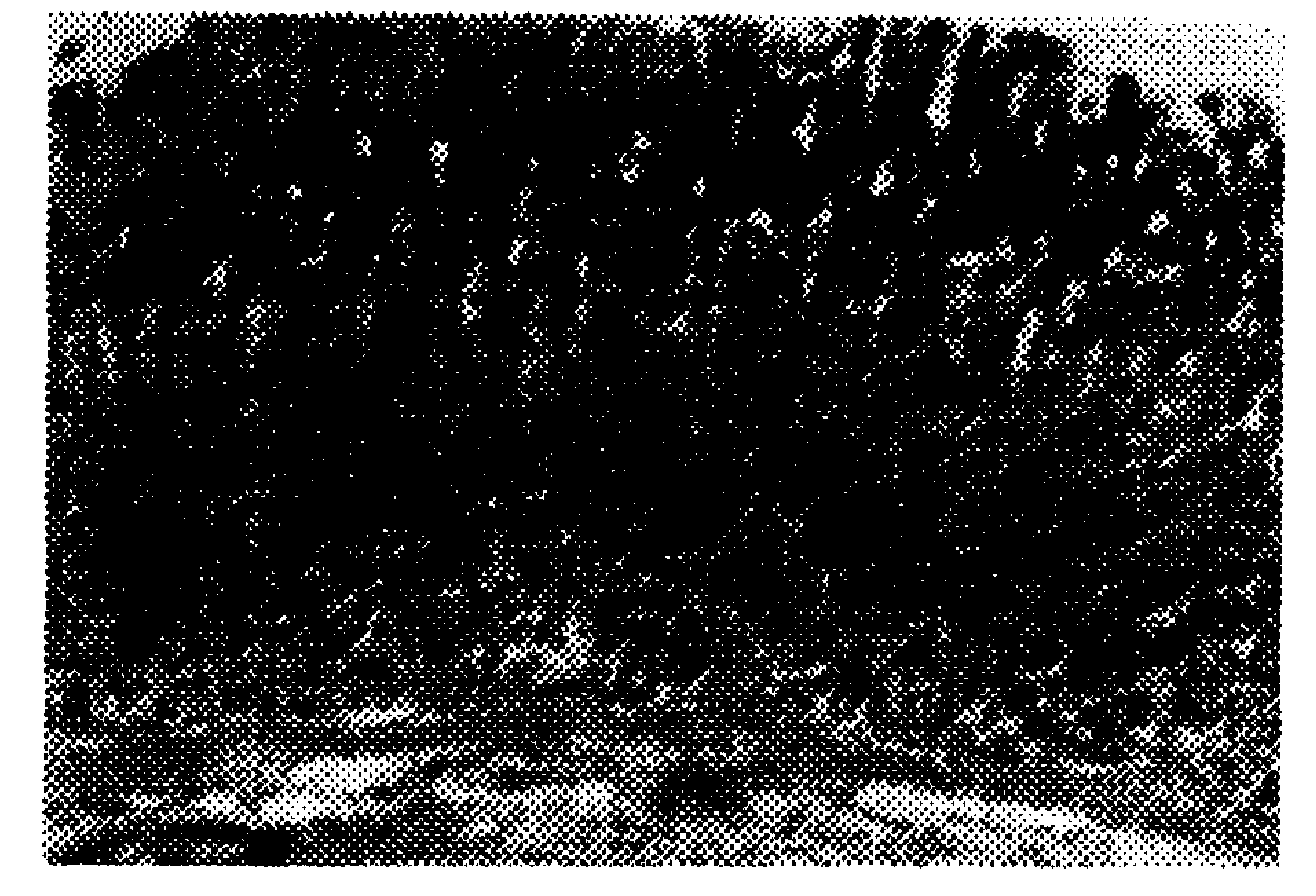

Fig. 9: Normal gastric mucosa of a control non treated rat (H \& E 200).

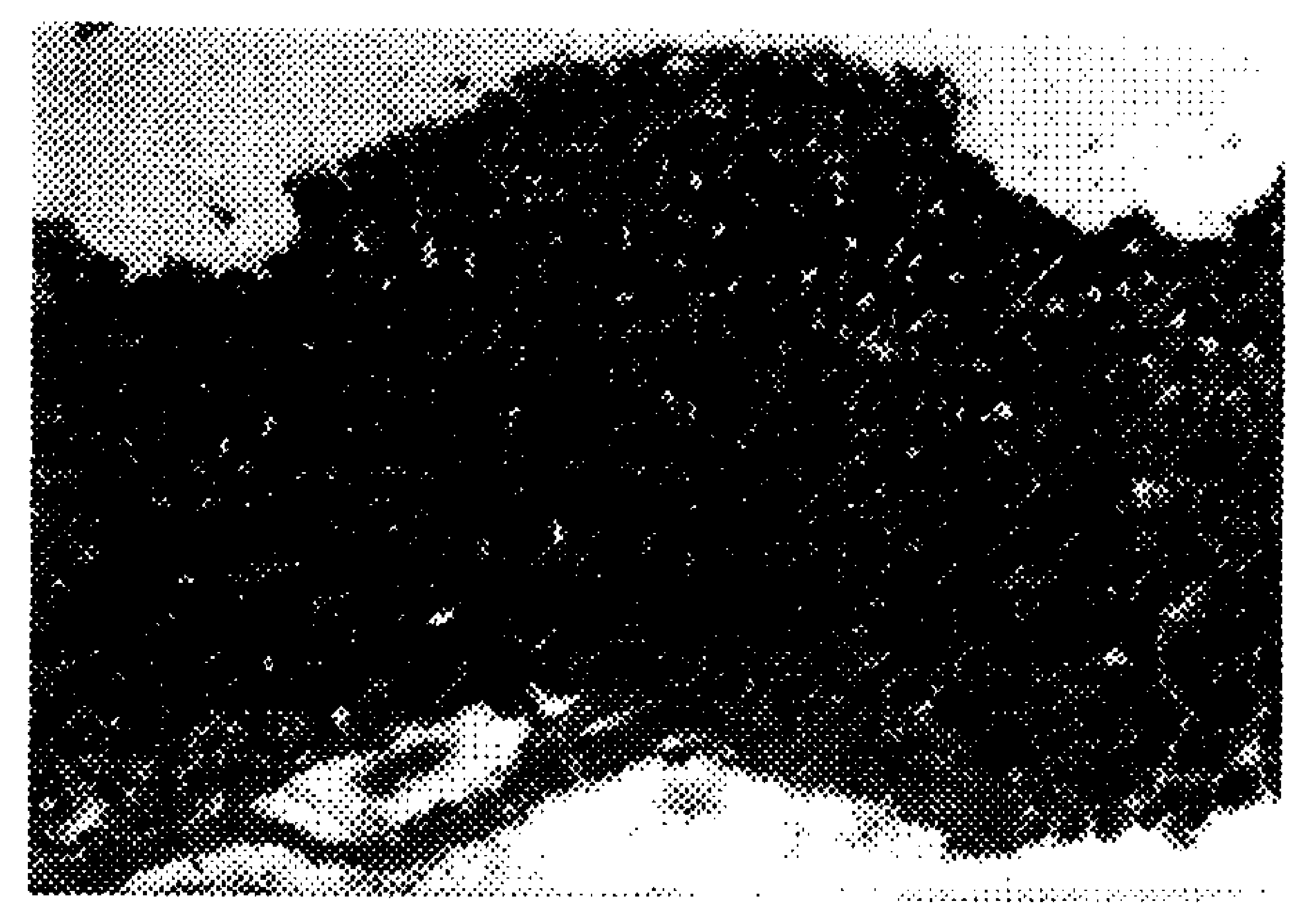

Fig.10: Gastric mucosa of a rat after oral administration of untreated ibuprofen ( $\mathrm{Hx} \&$ Ex 200).

The gastric mucosa of rats administered plain drug showed marked destruction or ulceration with complete disappearance of mucosal surface epithelium (Fig. 10). In addition, the gastric mucosa of rats administered ibuprofen/Aerosil 200 granules showed a slight ulceration in the lining epithelial of the fundic mucosa, but still less delterious than that plain ibuprofen (Fig. 11c). The gastric mucosa of rats given coevaporates of ibuprofen with either ethylcellulose or Eudragit seemed to decrease the ulcerogenic effects of ibuprofen (Figs. 11a\&b). A typical normal gastric mucosa was observed in the stomach of rats administered ibuprofen/Eudragit or ibuprofen/ethylcellulose coevaporates. Ethylcellulose significantly inhibits the ulcerogenic effect of ibuprofen. (a)

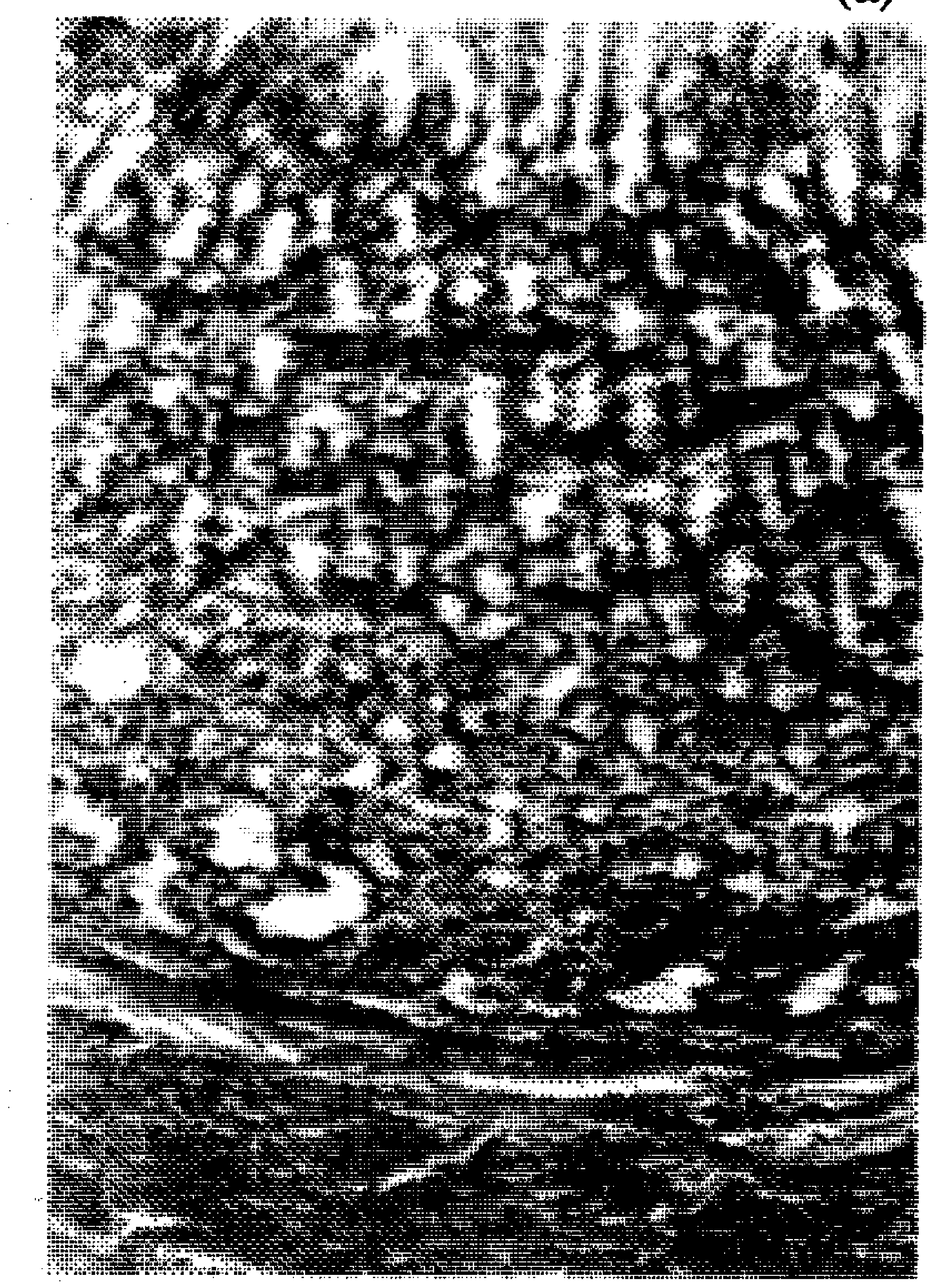

(b)

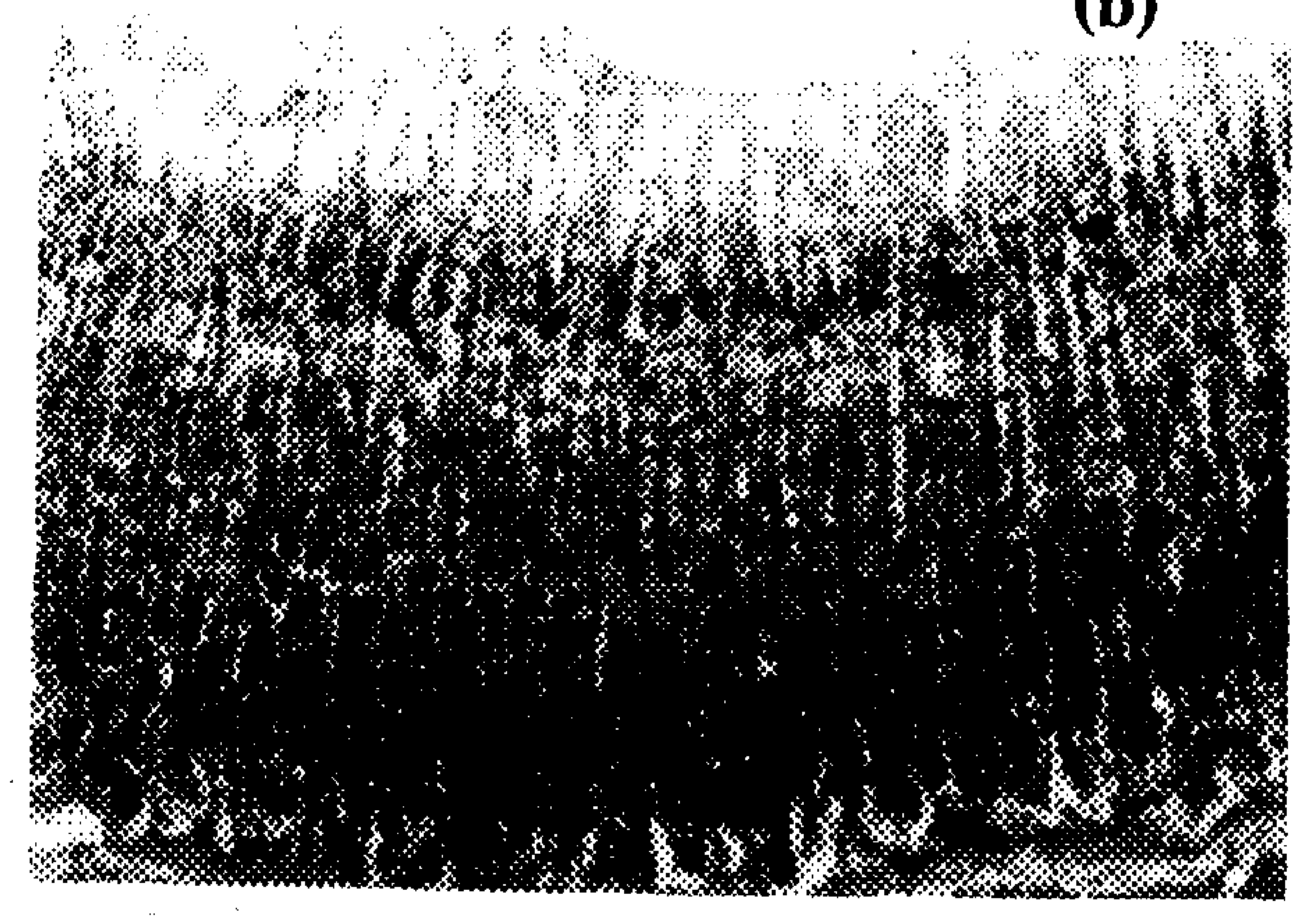

(c)



Fig.11: Gastric mucosa of a rat after oral administration of coevaporates granules (a) ibuprofen/ethylcellulose; (b) ibuprofen/ Eudragit RSPM and (c) ibuprofen/Aerosil 200 (Hx \& Ex 200). 
The obtained results from histological examination are well correlated with the in vitro release of the drug in artificial gastric fluid. Hence, the coevaporates of ibuprofen/Aerosil 200 granules showed the highest release rate of the drug in gastric fluid ( $\mathrm{pH} \mathrm{1.5).}$

In conclusion, coevaporates of ibuprofen with these carriers can be used to minimiz the side effects of the drug on the gastrointestinal tract as well as prolonged the antiinflammatory and the analgesic activities of ibuprofen.

\section{REFERENCES}

1- United States Pharmacopeial, DI, Drug Information for the Health Care Professional, Volume IA, Eighth Edition, (1988), pp. 350-365.

2- R.J.Flower, S.Moncada and J.R.Vane, in"Pharmacological Basis of Therapeutics", A.G.Gilman, L.S.Goodman and A.Gilman, eds., Mc Millan Publishing Co., Inc., New York, pp. 682 (1980).

3- K.R.Kurumaddall, W.R.Ravis and G.V.Betageri, Drug Dev. Ind. Pharm., 20 (7) 2659 (1994).

4- M.A.Christianah and C.P.James, Pharmaceutical Research, 8, 11 (1991).

5- A.A.Abd.Rahman, S.I.Abd.Rahman, A.E.Aboutaleb, A.Stamm, E.M.Samy, Eur. J. Pharm. and Biopharm., 38 (2), 71 (1992).

6- E.M.Samy, Saudi Pharm. J., 3, 1-2, 48 (1995).

7- P.P.Golikov, Farmakol. Toxikal., 6, 742 (1964).

8- N.B.Eddy, D.Leimbach, J. Pharmacol. Exp. Ther., 107, 385 (1953).

9- R.Okun, S.C.Liddon, L.Lasagna, J. Pharmacol. Exp. Ther., 139, 107 (1963).

10- D.J.Hingson, S. Ito, Gastroenterology, 61, 156 (1971).

11- A.Stamm, Labo. Pharm-Probi Tech., 29, 81 (1981).

12- S.Esezobo, J.Pharm. Pharmacol., 37, 193 (1985).

13- "Handbook of Pharmaceutical Excipients" A joint Publication of the Pharm.Socie. of
Great Britain and the Amer. Pharm. Assoc., Pharmaceutical Press, London, pp. 253 (1986).

14- T.Higuchi, L.M.Elowe and L.W.Busse, J. Amer. Pharm. Assoc., (Sci. Ed.), 43, 685 (1954).

15- T.Higuchi, A.R.Narshimha, L.W.Busse and J.V.Swintosk, J. Amer. Pharm. Assoc., 42, 199 (1953).

16- E.H.Wiseman and N.J.Federici, J. Pharm. Sci., 57, 1535 (1968).

17- C.D.Herzfeldt and R.Kummel, Drug Dev. Ind. Pharm., 9, 767 (1983).

18- F.Carli, G.Capone, I.Colombo and A.Motto, Int. J. Pharm., 21, 317 (1984).

19- V.Zecchi, A.Tartarini, I.Orienti, L.Rodrigulz, M. Cini, U. Cante and A.Fini, Pharm. Acta Helv., 61, 12, 322 (1986).

20- E.Sandell, Pharmaceutics Galenical Pharmacy, pp. 159 (1968).

21- H.E.Huber and G.L.Christenson, J. Pharm. Sci., 57, 164 (1968).

22- M.Nakano, N.Ohmori, A.Ogata, K. Sugimoto, Y.Tobino, R. Iwaoku and K. Juni, J. Pharm. Sci., 72, 378 (1983).

23- H.Lapidus and N.G.Lordi, J. Pharm. Sci., 57, 1292 (1968).

24- P.V.Aerde and J.P.Remon, Int. J. Pharm., 45, 145 (1988).

25- C.Brossard, D.Y.Lefert, D.Duchene, F.Puisieux and J.T.Carstensen, J. Pharm. Sci., 72, 2, 162 (1983).

26- J.T.Carstensen, Mechanical properties and rate process in solid pharmaceutics, Academic, New York, N.Y., pp. 224 (1980).

27- O.Cruaud, D.Duchene, F.Puisieux and J.T.Carstensen, J. Pharm. Sci., 69, 607 (1980).

28- R.W.Korsmeyer, R.Gurny, E.Doelker, P.Buri and N.A.Peppas, Int. J. Pharm., 15, 25 (1983).

29- J.E.Hogan, Drug Dev. Ind. Pharm., 15 (6\&7) 975 (1989).

30- J.Akbuga, Int. J. Pharm., 89, 19 (1993). 